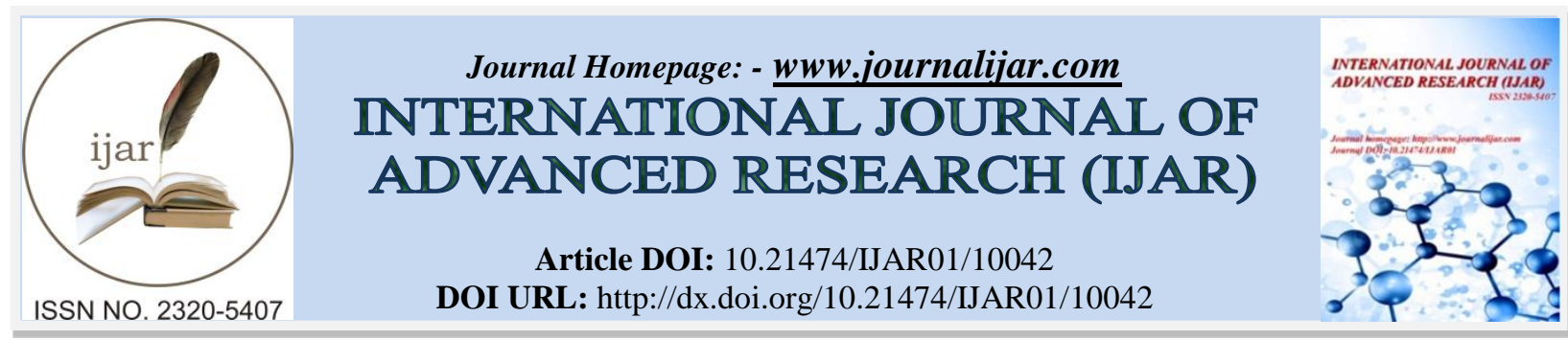

RESEARCH ARTICLE

\title{
EVALUATION OF SERUM LIPASE LEVEL IN NON DIABETIC CHRONIC KIDNEY DISEASE PATIENTS.
}

Sarla Mahawar, Deepa Thadani, Anupam lata jakhalia, Varsha Chowdhry and Asha Makwana. Professor, Sr.Professor \& Head, MD, Assistant Professor Assistant Professor Department of Biochemistry JLN Medical College, Ajmer, Rajasthan, India.

\section{Manuscript Info}

Manuscript History

Received: 10 September 2019

Final Accepted: 12 October 2019

Published: November 2019

\section{Key words:-}

Chronic kidney disease (CKD), Endstage renal disease (ESRD), Glomerular filtration rate (GFR), Chronic renal failure (CRF).

\section{Abstract}

Background: Chronic kidney disease is a progressive loss in renal function over period of many months or years. There is decline in nephron function and number generally quantitated as reduction in glomerular filtration rate. As the GFR declines there is accumulation of metabolic end products excreted by kidney. Serum lipase is mainly marker of pancreatic \& hepatobiliary disease but its level is also high in chronic renal disorder. Lipase is filtered by glomerulus and almost completely reabsorbed and metabolised by renal tubules, thus chronic kidney disease patient have elevated serum lipase level. Our study was aimed to find out the status of serum lipase in non diabetic chronic kidney disease subjects and healthy controls.

Materials and Methods: The present study is a case control study, conducted on 100 non diabetic chronic kidney disease patients . Cases were selected from Urology and Medical ward of Jawahar Lal Nehru Medical College and Associated Group of Hospitals, Ajmer. Age and sex matched healthy controls $(n=50)$ were selected from MOPD of Jawahar Lal Nehru Medical College and Associated Group of Hospitals, Ajmer. The present study is approved by Institutional Ethical Committee.

Results: The mean activity of serum lipase was significantly higher in non diabetic chronic kidney disease subjects compared to that in the healthy controls $(p<0.0001) .85$ out of 100 non diabetic chronic kidney disease patients have higher serum lipase levels than normal (>70 U/L).

Conclusion: Serum lipase level was found to be elevated in non diabetic chronic kidney disease patients. The observations of this study has also revealed that 85 out of 100 non diabetic chronic kidney disease patients have higher serum lipase levels than normal (>70 U/L). Serum lipase as a diagnostic tool in recognizing acute pancreatitis leads to false positive results in chronic kidney disease patients. Serum lipase can be used as a biomarker for the early detection of chronic kidney disease in the general population to prevent the morbidity and mortality which are associated with chronic kidney diseases.

Copy Right, IJAR, 2019,. All rights reserved.

Corresponding Author:-Sarla Mahawar. 


\section{Introduction:-}

Chronic kidney disease (CKD) is a worldwide health problem, affecting millions of people [1].

CKD is a type of kidney disease in which there is gradual loss of kidney function over a period of months or years [2,3]. CKD represents a progressive, irreversible decline in glomerular filtration rate (GFR) [4]. All kidney diseases progress to terminal renal failure relatively independent of the initial disease. Diabetic nephropathy, chronic glomerular diseases and hypertensive nephrosclerosis are among the most widespread causes of CKD [5]. Most chronic nephropathies unfortunately lack a specific treatment and progress relentlessly to end-stage renal disease (ESRD). Progressive renal function loss is a common phenomenon in renal failure, irrespective of the under-lying cause of the kidney disease [6]. Causes of chronic kidney disease include diabetes, high blood pressure, glomerulonephritis, and polycystic kidney disease [3,7]. Other health conditions that may lead to CKD are obesity, high cholesterol, a family history of the disease, lupus, and other forms of cardiovascular diseases.

The primary disease eventually leads to secondary glomerular injury and nephron loss that is clinically characterized by proteinuria and hypertension, which leads to inflammation or scarring which causes kidney failure and ultimately a gradual elevation in the plasma creatinine concentration and a progressive decline in GFR [8]. The excessive protein filtration, caused by the glomerular hypertension, might per se have toxic effects on the kidneys and increase the rate of progression[9]. Serum lipase is mainly marker of pancreatic \& hepatobiliary diseases but its level is also high in chronic renal disorder. Lipase is an enzyme that catalyses the breakdown of triglycerides[10]. In addition to pancreatic acinar cells, lipase is found in the gastrointestinal tract, including the oesophagus, duodenum, stomach and colon[10]. Lipase has also been described in the liver, heart, lungs and leukocytes[10,11]. The serum amylase and lipase are frequently elevated in patients with CRF in the absence of clinical pancreatitis[12]. Lipase is filtered by glomerulus and almost completely reabsorbed and metabolised by renal tubules. The serum pancreatic enzymes are often elevated within three-folds normal in ESRD patients. Thus, acute pancreatitis must be considered if enzyme levels are more than three-folds normal in association with clinical manifestations[13]. Blood urea and serum creatinine are widely accepted and most commonest parameters to assess renal functions. In India 8-10\% of adult population have some form of renal disorder. If CKD is detected early and managed appropriately the detoriation in kidney functions can be slowed and risk of cardiovascular diseases in renal patients can be reduced. Our study was aimed to find out the status of serum lipase level in non diabetic chronic kidney disease patient and healthy controls.

\section{Materials And Methods:-}

The present study is a case control study, conducted on 100 non diabetic chronic kidney disease patients . Patients were diagnosed as chronic kidney disease on the basis of clinical history, physical examination \& serum urea and serum creatinine level. Cases were selected from Urology and Medical ward of Jawahar Lal Nehru Medical College and Associated Group of Hospitals, Ajmer. Age and sex matched healthy controls $(n=50)$ were selected from MOPD of Jawahar Lal Nehru Medical College and Associated Group of Hospitals, Ajmer. The results of patients were compared with healthy controls $(n=50)$. The present study is approved by Institutional Ethical Committee.

\section{For control group}

Healthy individuals age and sex matched without renal disease.

\section{Inclusion criteria for study group}

Subject who is established case of chronic kidney disease

\section{Exclusion criteria for study group}

1. Patients having history of diabetes.

2. Patients admitted in ICU in state of shock

3. Renal transplant patients.

4. 4.The cases of intra-abdominal pathologies arising from the stomach, bowel and hepatobiliary tract and from neoplastic disease.

Blood samples were collected after an overnight fast (12-14hrs) under aseptic conditions from all the study participants. All samples were centrifuged and analysed for blood sugar, serum urea and serum creatinine and serum 
lipase. The blood sugar was measured by enzymatic GOD-POD end point method. Serum urea was measured by enzymatic end point colorimetric method. Serum creatinine was measured by Jaffe's colorimetric kinetic method. Serum lipase was measured by colorimetric kinetic assay. The normal serum lipase level is 12-70 U/L.

\section{Statistical analysis:-}

All data were analysed by SPSS-13 version. $\mathrm{P}<0.01$ were considered as significant.

\section{Results:-}

A total of 150 subjects were studied. The results are summarized in Tables and Figures. The Table-1, Figure-1 show the Mean \pm SD of blood sugar, serum urea, serum creatinine and serum lipase. The Table-1, Figure- 1 show Mean \pm SD of blood sugar $(95.6 \pm 12.3 \mathrm{v} / \mathrm{s} 83.8 \pm 8.4) \mathrm{mg} / \mathrm{dl}$, serum urea $(189.9 \pm 67.74 \mathrm{v} / \mathrm{s} 23.36 \pm 6.7) \mathrm{mg} / \mathrm{dl}$, serum creatinine $(6.4 \pm 2.6 \mathrm{v} / \mathrm{s} 0.86 \pm 0.52) \mathrm{mg} / \mathrm{dl}$ and serum lipase $(112.3 \pm 37.62 \mathrm{v} / \mathrm{s} 32.53 \pm 13.12) \mathrm{U} / \mathrm{L}$ in non diabetic chronic kidney disease subjects compared to healthy controls were significantly $(\mathrm{P}<0.0001)$ raised. 85 out of 100 non diabetic chronic kidney disease patients have higher serum lipase levels than normal ( $>70 \mathrm{U} / \mathrm{L}$ ). The Table-2, Figure- 2 show the serum lipase level in non diabetic chronic kidney disease subjects.

Table 1:-Biochemical Parameters of Healthy Control Subjects v/s Non Diabetic Chronic Kidney Disease Subjects

\begin{tabular}{|c|c|c|c|}
\hline $\begin{array}{l}\text { Biochemical } \\
\text { Parameters }\end{array}$ & $\begin{array}{l}\text { Healthy Control } \\
\text { Subjects } \\
\mathrm{n}=\mathbf{5 0} \\
\text { Mean } \pm \text { SD }\end{array}$ & $\begin{array}{l}\text { Non Diabetic Chronic } \\
\text { Kidney Disease Subjects } \\
\text { n=100 } \\
\text { Mean } \pm \text { SD }\end{array}$ & $\begin{array}{l}\text { P } \\
\text { VALUE }\end{array}$ \\
\hline Sugar $(\mathrm{mg} / \mathrm{dl})$ & $83.8 \pm 8.4$ & $95.6 \pm 12.3$ & $<0.0001$ \\
\hline $\begin{array}{l}\text { Urea } \\
(\mathrm{mg} / \mathrm{dl})\end{array}$ & $23.36 \pm 6.7$ & $189.9 \pm 67.74$ & $<0.0001$ \\
\hline $\begin{array}{l}\text { Creatinine } \\
\text { (mg/dl) }\end{array}$ & $0.86 \pm 0.52$ & $6.4 \pm 2.6$ & $<0.0001$ \\
\hline $\begin{array}{l}\text { Lipase } \\
\text { ( U/L) }\end{array}$ & $32.53 \pm 13.12$ & $112.3 \pm 37.62$ & $<0.0001$ \\
\hline
\end{tabular}

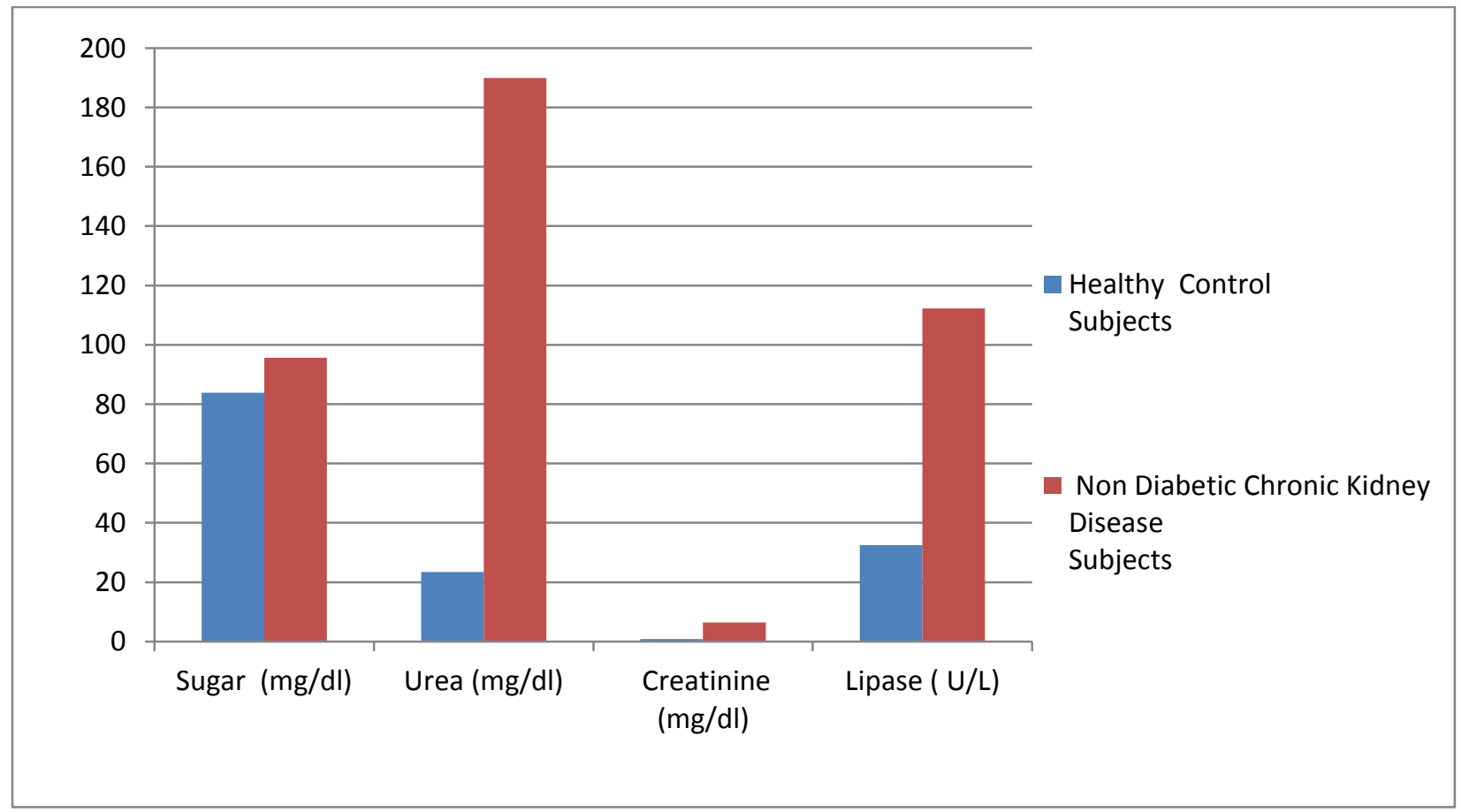

Fig 1:-Comparision of Biochemical Parameters of Healthy Control Subjects V/S Non Diabetic Chronic Kidney Disease Subjects 
Table 2:-Serum Lipase level in Non Diabetic Chronic Kidney Disease Subjects

\begin{tabular}{|l|l|}
\hline Serum Lipase level & \% Of Non Diabetic Chronic Kidney Disease Subjects \\
\hline$<70$ & $15 \%$ \\
\hline $\mathbf{7 0 - 1 0 0}$ & $30 \%$ \\
\hline $\mathbf{1 0 1 - 1 5 0}$ & $35 \%$ \\
\hline above 151 & $20 \%$ \\
\hline
\end{tabular}

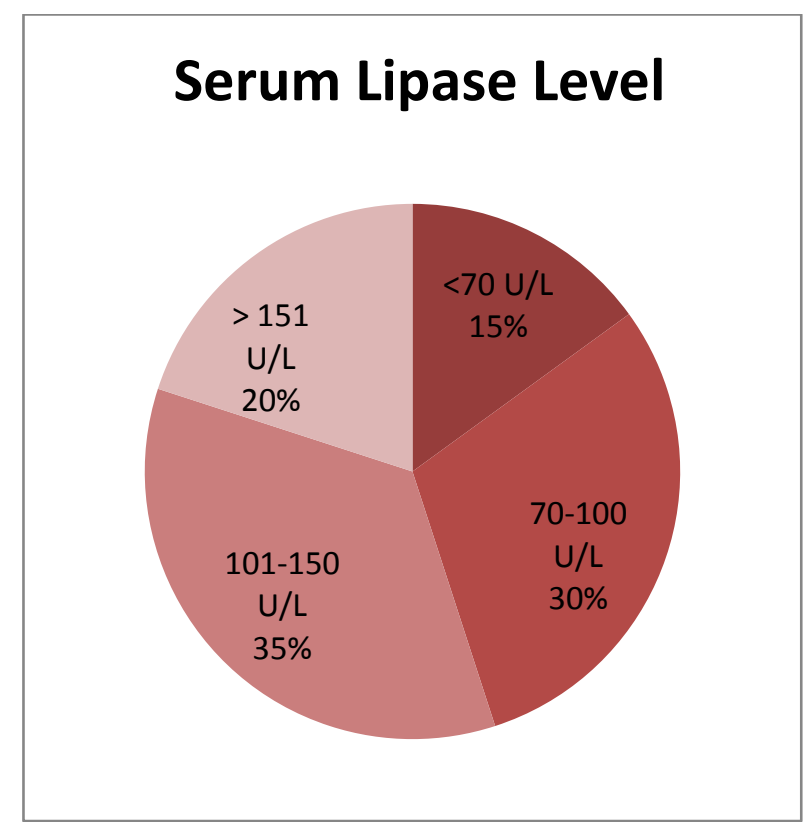

Fig 2:-Serum Lipase level in Non Diabetic Chronic Kidney Disease Subjects

\section{Discussion:-}

Chronic kidney disease (CKD) is a worldwide health problem, affecting millions of people [1]. Causes of chronic kidney disease include diabetes, high blood pressure, glomerulo- nephritis and polycystic kidney disease[3,7]. Other health conditions that may lead to CKD are obesity, high cholesterol, a family history of the disease kidney disease, lupus and other forms of cardiovascular diseases.

In the present study we have observed the level of serum lipase was elevated in non diabetic chronic kidney disease patients as compared to the healthy subjects (controls). It is in concordance with the previous studies which also state that the serum lipase was elevated in chronic kidney disease patients [12,13,14].

Our finding are in agreement with Jiange et al. (2002) found that the mean activity of serum lipase was significantly higher in chronic kidney disease patients campared to the Healthy subjects (controls) $(\mathrm{p}<0.0001)$ and reported that the serum pancreatic enzymes are often elevated within three-folds normal in ESRD patients. Thus, acute pancreatitis must be considered if serum lipase levels are more than three-fold normal in association with clinical manifestations [13].

Serum lipase is mainly marker of pancreatic \& hepatobiliary disease but its level is also high in chronic renal disorder. Twenty percent of pancreatic enzymes are excreted by the kidney. Thus patients with end stage renal disease have elevated levels of serum pancreatic enzymes. Serum lipase levels are increased in patients with renal insufficiency due to decreased excretion of the enzyme. The levels are not as high as pancreatitis, lipase is filtered by glomerulus and almost completely reabsorbed and metabolised by renal tubules. Reduced clearance of lipase from the circulation can occur with chronic renal failure $[15,16,17]$. The observations of this study also revealed that 85 out of 100 non diabetic chronic kidney disease patients have higher serum lipase levels than normal $(>70$ 
U/L). Serum lipase can be used as a biomarker for the early detection of chronic kidney disease in the general population to prevent the morbidity and mortality which are associated with chronic kidney disease.

\section{Conclusion:-}

Serum lipase was found to be elevated in non diabetic chronic kidney disease patients. Serum lipase as a diagnostic tool in recognizing acute pancreatitis leads to false positive results in chronic kidney disease patients. The observations of this study has also revealed that 85 out of 100 non diabetic chronic kidney disease patients have higher serum lipase levels than normal (>70 U/L).

Serum lipase can be used as a biomarker for the early detection of chronic kidney disease in the general population to prevent the morbidity and mortality which are associated with chronic kidney disease.

\section{References:-}

1. Di Angelantonio E, Danesh J, Eiriksdottir G. Renal function and risk of coronary heart disease in general populations: new prospective study and systematic review. PLOS Med $2007 ; 4$ : $1497-1507$

2. Liao, Min-Tser; Sung, Chih-Chien; Hung, K . "Insulin Resistance in Patients with Chronic Kidney Disease". Journal of Biomedicine and Biotechnology Volume 2012 (2012), Article ID 691369,12 pages doi:10.1155/2012/691369

3. Clatworthy. Kidney failure, also known as end-stage kidney disease, is a medical condition in which the ..... up to: "What is renal failure?". Johns Hopkins Medicine. Archived from the original on 18 June 2017. Retrieved 18 December 2017.

4. Brenner BM and Anderson S. The inter relationships among filtration surface area, blood pressure and chronic renal disease. Journal of Cardiovascular Pharmacology1992;19 (suppl 6):S1-7

5. Remuzzi G., Ruggenenti P. and Benigni A. (1997) Understanding the nature of renal disease progression. Kidney Int 1997; 51(1): 2-15.

6. Ots M, Pechter U and Tamm A. Characteristics of progressive renal disease. Clinica Chimica Acta 2000; 297:29-41.

7. GBD 2015 Mortality and Causes of Death, Collaborators. "Global, regional, and national life expectancy, allcause mortality, and cause-specific mortality for 249 causes of death, 1980-2015: a systematic analysis for the Global Burden of Disease Study 2015".(8 October 2016). Lancet. 388 (10053): 1459-1544

8. Jacobson H.R. Chronic renal failure: pathophysiology. 1991(Aug17); Lancet :338 (8764) :419-42

9. Tryggvason K. and Pettersson E. Causes and consequences of proteinuria: the kidney filtration barrier and progressive renal failure. 2003;J Intern Med 254(3):216-224.

10. Tietz NW, Shuey DF. Lipase in serum - the elusive enzyme: an overview. 1993; Clin Chem 39(5):746-756.

11. Lott JA, Lu CJ. Lipase isoforms and amylase isoenzymes: assays and application in the diagnosis of acute pancreatitis.1991;Clin Chem 37(3):361-368.

12. Royse VL, Jensen DM, Corwin HL (1987). Pancreatic enzymes in chronic renal failure. 1987(Mar); Arch Intern Med.147 (3):537 -539.

13. Jiang CF, Ng KW, Tan SW, Wu CS, Chen HC, Liang CT, Chen YH. Serum level of amylase and lipase in various stages of chronic renal insufficiency. Zhonghua Yi Xue Za Zhi (Taipei).2002; 65(2):49 -54.

14. Vaziri ND, Chang D, Malekpour A, Radaht S. Pancreatic enzymes in patients with end-stage renal disease maintained on hemodialysis. Am J Gastroenterol 1988; 83(4) :410-412

15. Lott JA, Patel ST, Sawhney AK, Kazmierczak SC, Love JE Jr. (1986) Assays of serum lipase: analytical and clinical considerations. Clin. Chem. 1986; 32(7):1290-1302.

16. Chen CC, Wang SS, Chen TW, Jap TS, Chen SJ. Serum procarboxypeptidase B, amylase and lipase in chronic renal failure. J Gastroenterol Hepatol .1996; 11:496-499.

17. Masoero G, Bruno M, Gallo L, Colaferro S, Cosseddu D, Vacha GM.(1996) Increased serum pancreatic enzymes in uremia: relation with treatment modality and pancreatic involvement. .. Pancreas. 1996 (Nov);13(4):350-355. 